\title{
Mapping the Future Cultural Policy of the European Union:
}

\section{The Intersection of Digital Communication, New Media and Progressive Cultural Politics}

Hvordan kan EU's kulturpolitik komme til at se ud når EU for alvor begynder at tage hensyn til den ny kulturelle situation med ny medier og digitale kulturer? Det er hovedspørgsmålet i mit ph.d.-projekt med arbejdstitlen Mapping the Future Cultural Policy of the European Union: The Intersection of Digital Communication, New Media and Progressive Cultural Politics. For at give et svar vil jeg forsøge at bruge en udvidet udgave af kritisk teori til at konstruere en model der er kompleks nok til at indfange de voldsomme aktuelle forandringer i det kulturelle landskab, og modellens rolle er bl.a. at reagere på disse forandringer og foreslå løsninger på nogle af de problemer som kulturens digitalisering og visualisering har skabt.

\section{KULTURPOLITIK}

En af kulturpolitikkens roller er at formidle kultur til den almene befolkning. Denne formidling består af komplekse interaktioner og sammenstød mellem forskellige aktører på det kulturelle felt, f.eks. mellem stat, marked, kunstnere, producenter, forbrugere, kulturelle institutioner, firmaer, globale sammenslutninger, kommuner, græsrødder, medier og store internationale institutioner som EU og FN. Deres indflydelse og formål er selvfølgelig meget forskellige, men hvad de bl.a. har til fælles, er deres ønske om at beskytte egne interesser og dermed at præge kunstens og kulturens rolle og udvikling i samfundet. Magtfulde aktører er med til at definere hvad der kan opfattes som kvalitet og værdigt til understøttelse - og i nogle tilfælde til masseforbrug. Derigennem kan disse aktører få stor indflydelse på samfundets udvikling og ikke mindst på befolkningens identitetsdannelse.

Imidlertid ligger der meget forskellige interesser bag de forskellige aktørers handlen, og dette er også tilfældet nu hvor nøgleord som globalisering og digitalisering spiller en hovedrolle i den kulturpolitiske debat. Det er derfor vigtigt at moderne kulturpolitik tager højde for digitaliseringen og den visualisering som den går hånd $\mathrm{i}$ hånd med. Her står en institution 
som EU stærkere end de enkelte nationalstater, da den fremtidige digitale kulturpolitiske debat i bund og grund er international.

Forholdet mellem magtrelationer, finansiel gevinst og befolkningens ret til information inden for den kulturelle sfære har ændret sig meget på grund af digitalisering og brugen af nye muligheder som World Wide Web. Kulturbrugernes interaktion med kulturen har også ændret sig, som Lev Manovich påpeger med følgende ord: "As distribution of all forms of culture becomes computer-based, we are increasingly 'interfacing' to predominantly cultural data - texts, photographs, films, music, virtual environments. In short, we are no longer interfacing to a computer but to culture encoded in digital form" (Manovich 2001: 69-70). Her er et påtrængende kulturpolitisk problem.

\section{KULTURENS DIGITALISERING}

Den digitale kultur ses tydeligst $\mathrm{i}$ internettet og især i weben, som er en kolossal database af tekster, grafik, fotografer, video, lyd, design, layout og softwarekoder, alt sammen gemt individuelt og derfor meget nemt for brugere at udnytte og manipulere med. Kulturens computerisering skaber derfor ikke kun nye kulturelle former, men omdefinerer ældre medier som tv, fotografi og film. Interaktion og participation med kulturelle objekter har også ændret sig betydeligt, og forskellen mellem kunstner og betragter er ikke den samme som før. Denne udvikling har resulteret i begrebet prosumer, dvs. forbrugeren (konsumenten) er i stigende grad også producer (Stalder 2001, 24. oktober). Nye medier skaber også hybrider hvor kunstneriske genrer blandes sammen, f.eks. internetkunst, og det skaber problemer for traditionel kulturpolitik.
Kulturpolitik har selvfølgelig mange forskel103 lige forpligtelser, f.eks. at stille kvantitative krav og konstruere kvalitative smagshierarkier. Den styrer, konstruerer og rekonstruerer kulturarven og stimulerer regional og national identitet samtidig med at den må tage multinationale og multietniske synspunkter i betragtning. Den prøver at imødekomme og udvikle befolkningens æstetiske opmærksomhed og dens erfaring og viden og at konstruere gode arbejdsforhold for både professionelle kunstnere og amatører. Kulturpolitik er også ansvarlig for at finansiere det kunstneriske felt, men metoderne kan variere meget alt efter statens, markedets, befolkningens eller de internationale institutionernes vægt og forhold til kulturpolitikken. Disse ansvarsområder er selvfølgelig ikke forsvundet med kulturens digitalisering, men feltet er simpelt hen blevet mere komplekst og omfattende end nogensinde før. Det betyder nye problemer og nye debatter som progressiv kulturpolitik bliver nødt til at tage stilling til.

\section{EU'S FREMTIDIGE KULTURPOLITIK}

Modellens hovedtilgang er derfor at forsøge at balancere nye medier og digital kommunikation på den ene side og progressiv kulturpolitik på den anden side, alt sammen med EU's kulturpolitik som empirisk forskningsramme. En international institution som EU er i en god position til at formulere en banebrydende politik der fuldt ud tager den globale kulturpolitiske debat i betragtning, og til at skabe en fælles forståelsesramme omkring nogle af de vigtigste kulturelle emner og udviklinger i det 21. århundrede: skabelsen af kritiske elektroniske offentligheder, den elektroniske distribution af kulturelle produkter, den ny forståelse af kunst-, kultur- og forfatterbegreberne, det ændrede 
104 forhold mellem producent og forbruger og ikke mindst ophavsrettens ændrede plads i den digitale tidsalder.

Kulturens digitalisering har skabt et vigtigt og omfattende paradigmeskifte hvad angår kunstens og kulturens rolle i samfundet, og hovedsigtet med mit projekt er at foreslå en måde EU's fremtidige kulturpolitik vil kunne håndtere det nye digitale paradigme på.

\section{LITTERATUR}

Manovich, Lev. 2001. The Language of New Media. The MIT Press, Massachusetts.

Stalder, Felix. 2001, 24th of October. "The End of an Era: The Internet Hits Ground”. URL: http://felix.openflows.org/html/endofera.html.

Bjarki Valtysson, Roskilde Universitetscenter, Institut for kommunikation, journalistik og datalogi, Postboks 260, 4000 Roskilde

E-mail:bjarki@ruc.dk 